\title{
Violence and torture against migrants and refugees attempting to reach the European Union through the Western Balkans
}

\author{
Marta Guarch-Rubio', Steven Byrne² and Antonio L. Manzanero3
}

\section{Key points of interest}

- Migrants and refugees during their transit through Europe are submitted to situations of ill-treatment and torture that add to the burden of the torture suffered in their country of origin.

\begin{abstract}
Introduction: The number of people being forcefully displaced is increasing and militarized border enforcement efforts have made migration a dangerous endeavour. The European Union is externalizing its borders, but migrants and refugees have not ceased arriving in Western societies despite facing violence and torture both throughout their journey, and at the gates of Europe. Method: 54 participants were assessed, 51 males and 3 females,
\end{abstract}

1) Marta Guarch-Rubio (Lecturer Assistant, University of Limerick (Ireland)).

Correspondence to: marta.guarchrubio@ul.ie

2) Steven Byrne (PhD Researcher, University of Limerick (Ireland)).

Correspondence to: steven.byrne@ul.ie

3) Antonio L. Manzanero (Professor, Universidad Compultense de Madrid

Correspondence to: antonio.manzanero@psi. ucm.es
26 were self-declared economic migrants and 28 stated that they fled due to political or religious persecution. The Iraqi version of the Harvard Trauma Questionnaire (HTQ) was adapted to collect traumatic and torture stressors experienced by the migrants/refugees during their stay in Western Bosnia, and more specifically during their detention and refoulement (push-backs) when attempting to cross the border between Bosnia-Herzegovina and Croatia. Results: $98.14 \%$ reported experiencing multiple forms of torture, $81.5 \%$ reported having their property looted, and $70.4 \%$ stated that they had been physically harmed during migratory transit. $50 \%$ of participants fulfilled the criteria for post-traumatic stress disorder (PTSD) due to the cumulative effect of traumatic experiences. Differences were found only in the amount of traumatic experiences between economic migrants and refugees who fled for political or religious reasons. No differences were found in torture experiences and PTSD diagnosis. Conclusions: Violence perpetrated by security forces against migrants is crystallized at the border-zones. Migrants are held in conditions that would amount by themselves to torture. Traumatic experiences have an effect on migrants/refugees' mental health and can trigger the development of post-traumatic stress disorder. Guaranteeing human rights for migrants/refugees throughout their journey is needed. 
Keywords: migrant, trauma, post-traumatic stress disorder, border, torture

\section{Introduction}

Increased coverage of the harmful effects of displacement and related violence experienced during migrants' journeys to host countries has begun to shine a light on the vulnerability they suffer both along the trip and at the border crossing (Arsenijević et al., 2017; Crepet et al., 2017; Farhat et al., 2018; Infante et al., 2012; Koning, 2019). Some have experienced beatings, sexual violence, torture and forced detention. As PérezSales (2018) points out, there is significant evidence of migrants' torture in their home country, during the migration process, during the asylum process and in humanitarian protection. During the migration process, kidnapping, extortion, trafficking, human rights violations and detentions at borders are frequent. However, some of these incidences are difficult to detect (Silva et al., 2018). The perpetrators are often smugglers, police/border agents and other migrants. During the asylum process, many other human rights violations may take place (Pérez-Sales, 2018), such as lack of access to the legal and healthcare system, detentions, delays in procedures, inappropriate interview processes and credibility assessments of allegations.

Examples of human rights violations against migrants can be found around the world, for example at the border between the United States and Mexico (Infante et al., 2012), in Libya (Beşer \& Elfeitori, 2018; Reques et al., 2019) or in Niger (Veronese, Pepe, \& Vigliaroni, 2019).

In Europe, there are actors who oppose inward migration, often presenting it as a threat to the nation state. Accordingly, coverage of the so-called "migrant crisis" has been criticized for attaching negative connotations to the terms migrant and refugee, rather than focusing on countries' management of the migratory phenomena (Karamanidou, 2016). Farhat et al. (2018) examined 728 Syrian refugees' experiences of violence during their journey, finding that, whilst they were in Greece, the main type of violence that refugees were subjected to was beatings, which were perpetrated by police in both Greece (33.3$82.3 \%)$ and Turkey (7.8-59.3\%). Along the migratory journey, migrants/refugees experience new potentially traumatic events that add to already harmful experiences prior to departing the country of origin. In Italy, Crepet et al. (2017) found that a large percentage of recently arrived migrants/refugees (89\%) experienced traumatic events along their journey. The most frequent events experienced were finding themselves in a situation of combat or at risk of death (29\%), detention/kidnapping (24\%) and kidnapping/torture (11\%).

Arsenijević et al. (2017) denounced a lack of protection for migrants/refugees crossing through Serbia. One out of three interviewees experienced a violent event perpetrated by state authorities. Systematic violence at the EU's external borders is a primary method of "gatekeeping" in international protection and aiding collective expulsion (Border Violence Monitoring Network, 2020). Despite the fact that the Central Mediterranean route remains the dominant path for migrants into Europe, there are also land routes on which migrants/refugees continue the trip on foot or by motor vehicle (El-Shaarawi \& Razsa, 2019). The country of origin and the characteristics of the route determine the typology of violence migrants experience during transit. For instance, the Balkan corridor is now an established alternative to the Mediterranean Sea but in itself, it remains replete with its own dangers and risks for migrants. 
Violent deterrence is not exclusively perpetrated throughout Europe; it also seems to be a wide buffering strategy to discourage migrants and refugees globally. In addition, second-country hosts are becoming less receptive, or even hostile, toward displaced persons (Holmes \& Casteñada, 2016).

\section{Psychological effects of violence on migrants and refugees}

Several studies have reported the effects of exposure to war and political violence on the civilian population in different countries. Steel et al.'s (2009) meta-analysis of 161 articles (181 surveys) reported rates of $30.6 \%$ for PTSD and $30.8 \%$ for depression. The variability observed across the different studies is due to a type of numerous factors, such as torture, number of and cumulative exposure to potentially traumatic events, time since conflict, residency status and assessed level of political terror (Steel et al., 2009).

Following the definition of torture by the United Nations Convention against Torture (UNCAT, 1984), the present paper examines violent and torture events as experienced by economic migrants and refugees during their period of transit and detention on the EU's borders between Croatia and Bosnia-Herzegovina. It also shows traumatic events as experienced by migrants during the migratory journey, in their home country and its impact on mental health as PTSD.

Current situation at the border crossing between Bosnia-Herzegovina and Croatia

Until relatively recently, Bosnia-Herzegovina was outside of any established migration route. Since 2015, however, with Hungary and Slovenia fortifying its borders, the socalled "Balkans route" emerged as one of the steps before arriving in the EU (Amnesty International, 2019; Meçe, 2018). From January
2018 to December 2019, 53263 refugees/migrants arrived in Bosnia-Herzegovina - over 2200 per month. Most of them were located in Sarajevo and close to the Western Croatian border (UNHCR, 2020).

Bosnia-Herzegovina stands out as a transit country; migrants/refugees have reported that they intend to settle in other destination countries such as Italy (27\%), France (18\%), Germany (14\%) and others (41\%) (IOM, 2020). Limited capacity and resources, along with the political stalemate and institutional dysfunction that has paralyzed the country since the end of the war in 1995, mean that Bosnia-Herzegovina has been ill-prepared to provide neither adequate protection nor living conditions for migrants (Amnesty International 2019). In addition, the locations that house migrants frequently contain a concentration of violence based on conditions of pervasive insecurity, the quantification of which is almost impossible to manage. Given this, by virtue of the complexity and volatility of the patterns of mobility as well as the diversity of experiences and itineraries of those who have arrived at the border, the situation at the border between Croatia and Bosnian-Herzegovina represents an auspicious place for research into how migrants are subjected to violence or bodily trauma when attempting to enter EU. During 2019, the BorderViolence Monitoring Network (2020) recorded 3,251 pushbacks from Croatia to Bosnia-Herzegovina, and from Greece to Turkey. Moreover, there is little quantitative documentation of the prevalence of violence among these migrants, their experiences on the border, their period of transit or time spend in detention centres.

In the present project, the initial goals were to evaluate the traumatic and torture events suffered by the migrants/refugees, and consequently the presence of PTSD. However, throughout observation in the field, a large 
number of people were detected being pushed back illegally to Bosnia-Herzegovina from Croatia. They usually returned wounded and without their property (mobile phones, money and other items such as bags, glasses and clothes). In their own words, when this occurred, they had "lost the game." The research goals were therefore adapted, focusing on the violence and inhuman and degrading treatment they experienced along the aforementioned border. To achieve this, we focused on the towns of Bihać and Velika Kladuša, two points on the Western Balkan route. This path extends from Turkey to Greece, passing through the former Yugoslav States and Hungary (Milan, 2019). Located on the border with Croatia in the northwest of Bosnia-Herzegovina, both towns had become a temporary refuge for between 5000 and 5500 migrants fleeing conflict, persecution and poverty (Amnesty International, 2019). In both these locations, there were institutional barracks that host migrants. However, not all migrants could access suitable accommodation due to overcrowding and restricted access to various services.

\section{Method}

\section{Participants}

Fifty-four participants were assessed, 51 males $(94.4 \%)$ and 3 females, of ages ranging between 17 and 41 years $(M=26.15$; $S D=$ 4.72). They were recruited in two ways: (1) referrals from local NGOs and (2) snowball as chain referrals by migrants living in Bihać and Velika Kladuša. The sample was obtained by asking members of the migrant population if they would take part freely in the research, as an opportunistic sample. All were deemed irregular migrants/refugees and were considered "on the move" as they were in transit in Bihać and Velika Kladuša (Bosnia-Her- zegovina) and waiting to travel further into EU, regardless of the official political status afforded to them. These two towns are two "hot spots" in the Western Balkan route, due to the number of violent pushbacks (unofficial deportations) that take place there.

In this study, the number of pushbacks considered as illegal deportations from Croatia to Bosnia-Herzegovina was understood as the number of attempts to cross the border; in their own words, the number of times they had "lost the game." Finally, it deserves to be mentioned that all migrants/refugees from the North of Africa had chosen the Balkan route in order to avoid crossing the Mediterranean Sea.

\section{Instruments and procedure}

The Arabic version of the Harvard Trauma Questionnaire (henceforth HTQ) adapted for the Iraqi population (Shoeb, Weinstein, \& Mollica, 2007) and a questionnaire specifically designed for this study were applied. The study includes those stressors that migrants/ refugees suffered in their home country, during other stages of their journey or perpetrated by other migrants or human smugglers. Consequently, the main body of this research focuses on the presence of traumatic events perpetrated on the external EU borders.

For the purposes of this research, we used the thirty-five binary "yes/no" questions from the torture section of the HTQ; for example, "Were you exposed to dirty conditions leading to ill health?" or "Were you humiliated and threatened?"

The fourth section of the HTQ measures the symptoms of trauma and is composed of 44 items that evaluate the severity or intensity of the symptoms on a 4-point Likert-type scale $(1=$ not at all, $2=$ a little, $3=$ quite a bit, $4=$ extremely). The first 16 items aim to measure PTSD symptoms according to Diagnostic and Statistical Manual of Mental Disor- 
ders (4th ed.; DSM-IV; American Psychiatric Association, 1994) criteria, with a threshold of 2.5 or higher. The other 28 items quantify what the authors name "refugee specific," which evaluates the impact that the traumatic events could have had on their perception of their own daily life. The Cronbach's alpha of the section in this sample was .939 and interitem correlation was .253.

Also, an adapted clinical questionnaire was used as it permitted for the collection of sociodemographic characteristics (age, marital status etc.); cause of the migration or length of the migratory journey.

Questionnaires were completed orally with a trauma psychologist completing the questionnaire in line with the respondent's answers. However, for the open questions interviewees also had the possibility of writing the answer in Arabic or another language. The interviews were conducted in English and individually. In addition, the questionnaires were written both in English and in Arabic, so the participants could also read the questions in both languages.

Table 1. Socio-demographic characteristics of migrants/refugees to survey $(N=54)$.

\begin{tabular}{|c|c|c|c|}
\hline & & $\mathbf{N}$ & $\%$ \\
\hline \multirow[t]{9}{*}{ Origin } & Algerian & 21 & 38.9 \\
\hline & Moroccan & 10 & 18.5 \\
\hline & Iraqi & 8 & 14.8 \\
\hline & Syrian & 8 & 14.8 \\
\hline & Palestinian & 2 & 3.7 \\
\hline & Tunisian & 2 & 3.7 \\
\hline & Lybian & 1 & 1.9 \\
\hline & Pakistan & 1 & 1.9 \\
\hline & Western Sahara & 1 & 1.9 \\
\hline \multirow[t]{2}{*}{ Sex } & Male & 51 & 94.4 \\
\hline & Female & 3 & 5.6 \\
\hline \multirow[t]{3}{*}{ Age Category (Years) } & $18-25$ & 29 & 53.7 \\
\hline & $26-34$ & 22 & 40.7 \\
\hline & $\geq 35$ & 3 & 5.5 \\
\hline \multirow[t]{3}{*}{ Marital Status } & Single & 47 & 87 \\
\hline & Married & 5 & 9.3 \\
\hline & Divorced & 2 & 3.7 \\
\hline \multirow[t]{2}{*}{ Progeny } & Yes & 6 & 11.1 \\
\hline & No & 48 & 88.9 \\
\hline \multirow[t]{2}{*}{ Reason of migration } & Better life & 26 & 48.1 \\
\hline & $\begin{array}{l}\text { Political/religious persecution and } \\
\text { war }\end{array}$ & 28 & 51.9 \\
\hline
\end{tabular}


The strategy was to have a flexible and dynamic approach to participant recruitment that took into consideration the ever-changing migration context in the region. Interviews were conducted between July and August 2019. As such, we spent time at NGOs, self-organised migrant camps and urban parks. It was here where migrants gathered to regroup or to share information.

\section{Ethical aspects}

This study is part of a larger research project which assesses the psychological needs of refugees and asylum seekers. It was approved by the Ethics Committee of Complutense University of Madrid (Spain), and declared of interest to the United Nations High Commissioner for Refugee (UNHCR) and the United Nations Relief and Works Agency for Palestine Refugees in the Near East (UNRWA).

Like other studies with migrant populations (Ibrahim \& Hassan, 2017) and for cultural and security reasons, informed consent was obtained verbally. As such, there were no exclusions based on gender or ethnicity.

\section{Results}

The socio-demographic characteristics and referral sources of the 54 migrants/refugees are shown in Table 1 . All of the interviewees were waiting for the opportunity to cross the border from Bosnia-Herzegovina into Croatia to get into the EU Schengen open border area and further into Europe. Nearly all the data collection was conducted in Velika Kladuša and the vast majority of the migrants/refugees were men and under 35 years old. Most interviewees were single and none of them travelled with dependent children. Participants in this research came mainly from countries in the Middle East and North Africa. Slightly over half of the refugees/migrants cited political and religious persecution as the motivating factors when deciding to leave their home country. As such, according to international law regarding the rights of refugees, they should have had the right to apply for asylum (UNHCR, 2019).

The largest declared country of origin was Algeria (38.9\%), followed by Morocco (18.5\%), Iraq (14.8\%) and Syria (14.8\%). The most migrants seeking to enter Europe do so through the Western Balkan route (IOM, 2020; UNHCR, 2020). However, this pattern is not necessarily representative of all migratory movements along this route, as this path to Europe tends to be continuously evolving. This is in line with the literature, which shows that this route intersects with other routes, with people travelling from Central Asia, the Middle East, North Africa and Sub-Saharan Africa (Crepet et al., 2017; El-Shaarawi \& Razsa, 2019). This emerging route shows how new migratory European policies divert the traditional routes from North Africa to Italy and increase arrivals through Turkey.

From a national perspective, the majority of the Algerians (81\%) who contributed to this

Table 2. Characteristics of the migration process.

\begin{tabular}{lll}
\hline & M & SD \\
\hline Length migratory journey (months) & 20.50 & 17.66 \\
Length stay in Bosnia-Herzegovina (months) & 5.84 & 5.03 \\
Number of deportations from Croatia to Bosnia-Herzegovina & 5.87 & 5.50
\end{tabular}


study cited "a better quality of life" as their motivation for travelling to Europe. In contrast and unsurprisingly, all Syrians (100\%) said that they left because of political persecution. This is in comparison to $75 \%$ of the Iraqis who stated that religious persecution was the main motivational factor in their decision to leave. Therefore, as mentioned before, slightly over half should have had the right to apply for asylum and have been considered as refugees according to their migratory status.

Overall, departure dates from the country of origin ranged from August 2012 to June 2019. However, in this study, most of the migrants/refugees left their home countries between December 2017 and June 2019. As Table 2 shows, the median length of their migratory journey was close to two years since they left their home country. However, the median length of time in Bosnia-Herzegovina was barely 6 months, with $22.2 \%$ of the interviewees spending 12 months in the country. The minimum period of stay was 10 days and the maximum was 2 years. Finally, 48 out of 54 participants attempted to cross the border at least once and were deported without due process or access to asylum procedures. The median number of attempts to cross the border was also close to six and $24.07 \%$ had tried to cross ten times or more. According to their statements, nobody had the opportunity to apply for asylum and were unlawfully deported to Bosnia-Herzegovina.

When the motive for migration is considered as an influencing factor, we found that there were no effects on the length of time they had stayed on the border between Bosnia-Herzegovina and Croatia, $F(1,52)=0.326, p=$ $.570, \eta^{2}=.006$; nor on the number of times they had been deported, $F(1,52)=2.155$, $p=.148, \eta^{2}=.040$. Migrants for economic reasons stayed an average of 187.69 days $(S D$ $=145.93)$, and $163.75(S D=160.86)$ days for refugees for political/religious reasons. The average number of deportations was 7.00 ( $S D$ $=6.23)$ for economic reasons, and $4.82(S D=$ 4.60) for political/religious reasons.

\section{Traumatic experiences}

The data shows that life in Bihać and Velika Kladuša was fraught with difficulties and hardships, and there was a high prevalence of instances of both violence and torture reported. In addition, for the migrants/refugees resident in Bihać and Velika Kladuša, the sense of insecurity and the frequent pushbacks were clearly issues. All the participants $(100 \%)$ stated that they had been subjected to traumatic experiences associated to their migratory experience. In addition, the vast majority (98.14\%) reported experiencing multiple forms of physical and psychological trauma during their push-back or attempted border crossing from Bosnia-Herzegovina to Croatia. Data from the first section of the HTQ revealed that $81.5 \%$ reported having their property looted, $70.4 \%$ stated that they had been physically harmed of which $46.3 \%$ maintained that they had been subjected to beatings to the head. $40.7 \%$ claimed that they had been physically tortured or perceived themselves as torture victims. Despite Table 3 showing all of the results, for this research we have selected just the three mentioned traumatic experiences (in bold in the table) because they took place according to their testimonies during their detention on the Croatian border. Moreover, regarding the item "physically harmed," 25 of the migrants added that they were beaten on the head. Therefore, this item was included as an extra item below "physically harmed." The rest of traumatic events, however, are not fully described in this research because participants stated that they had occurred throughout the whole migratory journey or in their home country. The expe- 
Table 3. Trauma events among migrants $(N=54)$ during their migration process. In bold letters specific events occurred in Bihać and Velika Kladuša during July-August 2019.

Sorted from highest to lowest frequency.

Trauma Events
Witnessed someone being physically harmed

Property looted, confiscated, or destroyed

Suffered from lack of food or clean water

Forced to flee your country

Physically harmed

Beatings to the head

$\%$

45

$44 \quad 81.5$

$43 \quad 79.6$

$40 \quad 74.1$

$38 \quad 70.4$

2546.3

Suffered ill health without access to medical care or medicine

Murder or violent death of friend

Disappearance of a friend

Searched

Present while someone searched for people or things in your home.

Witnessed rotting corpses

Witnessed torture

Witnessed murder

Forced to leave your hometown and settle in a different part of the

Witnessed shelling, burning, or razing of residential areas or

Serious physical injury of family member or friend from combat

\section{Tortured}

Expelled from country based on ancestral origin, religion, or sect

Witnessed the desecration or destruction of religious shrines

Murder or violent death of family member

Received the body of a family member

Friend kidnapped or taken as a hostage

Witnessed chemical attacks on residential areas or marshlands

Witnessed sexual abuse or rape

Someone informed on you placing you and your family at risk of injury

Disappearance of a family member

Forced to inform on someone placing them at risk of injury or death

Family member kidnapped or taken as a hostage

Used as a human shield

Serious physical injury from combat situation or landmine

Forced to physically harm someone

Forced to pay for bullet used to kill family member

Kidnapped or taken as a hostage

Forced to destroy someone's property

Sexually abused or raped (i.e., forced sexual activity) 
Table 4. Torture experiences among migrants in Bihać and Velika Kladuša $(N=54)$ during July-August 2019. Sorted from highest to lowest frequency.

\begin{tabular}{|c|c|c|}
\hline Torture experiences & $\mathrm{N}$ & $\%$ \\
\hline Exposed to rain or cold & 50 & 92.6 \\
\hline Deprived of food and water for long periods of time & 36 & 66.7 \\
\hline Deprived of medical care & 36 & 66.7 \\
\hline Exposed to dirty conditions leading to ill health & 35 & 64.8 \\
\hline Exposed to strong heat, sun or light & 32 & 59.3 \\
\hline Punched, slapped, kicked or stricken with objects & 30 & 55.6 \\
\hline Forced to stand for long periods of time & 29 & 53.7 \\
\hline Humiliated and threatened & 28 & 51.9 \\
\hline Deprived of sleep & 25 & 46.3 \\
\hline Exposed to continuous/piercing noise & 21 & 38.9 \\
\hline Prevented from urinating or defecating & 21 & 38.9 \\
\hline Chained or tied & 16 & 29.6 \\
\hline Forced to undress in front of people & 16 & 29.6 \\
\hline Placed in a sack, box or very small place & 15 & 27.8 \\
\hline Beaten on soles of feet with rods or whips & 14 & 25.9 \\
\hline Placed in an isolation cell with no clothes, toilet or ventilation & 14 & 25.9 \\
\hline Prohibited from ablution and prayer & 11 & 20.4 \\
\hline Forced labor & 8 & 14.8 \\
\hline Witnessed the sexual abuse, rape or torture of someone & 8 & 14.8 \\
\hline Electrocuted & 7 & 13.0 \\
\hline Forced to write false confessions & 7 & 13.0 \\
\hline Forcibly arranged in various humiliating or sexually explicit positions & 7 & 13.0 \\
\hline If 'yes', where you photographed & 3 & 5.6 \\
\hline Subjected to mock executions & 4 & 7.4 \\
\hline Blindfolded & 3 & 5.6 \\
\hline Stretched on a rock for long periods & 3 & 5.6 \\
\hline Burned by cigarettes, electrically heated rods, hot oil, fire, or corrosive acid & 2 & 3.7 \\
\hline Head submerged in water with near-drowning & 2 & 3.7 \\
\hline Suspended from a rod by hands and feet for longs period of time & 2 & 3.7 \\
\hline Sexually abused or raped & 1 & 1.9 \\
\hline Other experience of torture & 1 & 1.9 \\
\hline
\end{tabular}


Table 5. Frequencies, mean scores (M) and standard deviations (SD) for trauma symptoms among migrants in Bihać and Velika Kladuša ( $N=54)$ during July-August 2019. Sorted from highest to lowest scores.

\begin{tabular}{|c|c|c|c|c|c|c|}
\hline Trauma symptoms & $\begin{array}{c}\text { Not } \\
\text { at all }\end{array}$ & $\begin{array}{c}\text { A } \\
\text { Little }\end{array}$ & $\begin{array}{l}\text { Quite } \\
\text { a bit }\end{array}$ & Extremely & $\mathbf{M}$ & SD \\
\hline Trouble sleeping & 12 & 10 & 10 & 22 & 2.78 & 1.21 \\
\hline $\begin{array}{l}\text { Recurrent thoughts or memories of the } \\
\text { most hurtful or terrifying events }\end{array}$ & 5 & 19 & 14 & 16 & 2.76 & 0.99 \\
\hline $\begin{array}{l}\text { Feeling that you have no one to rely } \\
\text { upon but god }\end{array}$ & 14 & 5 & 15 & 20 & 2.76 & 1.21 \\
\hline Feeling exhausted & 8 & 18 & 11 & 17 & 2.69 & 1.08 \\
\hline Difficulty concentrating & 11 & 13 & 14 & 16 & 2.65 & 1.12 \\
\hline $\begin{array}{l}\text { Feeling irritable or having outbursts of } \\
\text { anger }\end{array}$ & 10 & 15 & 14 & 15 & 2.63 & 1.09 \\
\hline $\begin{array}{l}\text { Avoiding activities that remind you of } \\
\text { the hurtful event }\end{array}$ & 17 & 7 & 13 & 17 & 2.56 & 1.24 \\
\hline Feeling no trust in others & 7 & 19 & 19 & 9 & 2.56 & 0.92 \\
\hline $\begin{array}{l}\text { Feeling that you have less skills than } \\
\text { you did before. }\end{array}$ & 15 & 9 & 16 & 14 & 2.54 & 1.16 \\
\hline $\begin{array}{l}\text { Sudden emotional or physical reaction } \\
\text { when reminded of the most hurtful } \\
\text { events }\end{array}$ & 14 & 13 & 12 & 15 & 2.52 & 1.16 \\
\hline Less interest in daily activities & 18 & 6 & 17 & 13 & 2.46 & 1.19 \\
\hline $\begin{array}{l}\text { Ruminations, poor concentration, lack } \\
\text { of initiative, boredom, sleep problems, } \\
\text { tiredness, and somatic complaints }\end{array}$ & 17 & 9 & 14 & 14 & 2.46 & 1.19 \\
\hline Feeling as if you don't have a future & 19 & 7 & 13 & 15 & 2.44 & 1.24 \\
\hline Feeling on guard & 13 & 17 & 12 & 12 & 2.43 & 1.09 \\
\hline $\begin{array}{l}\text { Feeling that someone you trusted be- } \\
\text { trayed you }\end{array}$ & 21 & 5 & 12 & 16 & 2.43 & 1.28 \\
\hline Feeling humiliated by your experience & 20 & 8 & 11 & 15 & 2.39 & 1.25 \\
\hline $\begin{array}{l}\text { Feeling that others don't understand } \\
\text { what happened to you }\end{array}$ & 16 & 13 & 13 & 12 & 2.39 & 1.14 \\
\hline Sensation of the heart being squeezed & 17 & 12 & 12 & 13 & 2.39 & 1.17 \\
\hline $\begin{array}{l}\text { Avoiding thoughts or feelings associated } \\
\text { with the hurtful events }\end{array}$ & 16 & 13 & 14 & 11 & 2.37 & 1.12 \\
\hline $\begin{array}{l}\text { Feeling detached or withdrawn from } \\
\text { people }\end{array}$ & 19 & 14 & 6 & 15 & 2.31 & 1.23 \\
\hline $\begin{array}{l}\text { Feeling as though the event is happen- } \\
\text { ing again }\end{array}$ & 18 & 14 & 12 & 10 & 2.26 & 1.12 \\
\hline
\end{tabular}




\begin{tabular}{|c|c|c|c|c|c|c|}
\hline Trauma symptoms & $\begin{array}{c}\text { Not } \\
\text { at all }\end{array}$ & $\begin{array}{c}\text { A } \\
\text { Little }\end{array}$ & $\begin{array}{l}\text { Quite } \\
\text { a bit }\end{array}$ & Extremely & $\mathbf{M}$ & SD \\
\hline $\begin{array}{l}\text { Irritability, nervousness, lack of pa- } \\
\text { tience, and anger outbursts }\end{array}$ & 16 & 20 & 6 & 12 & 2.26 & 1.12 \\
\hline $\begin{array}{l}\text { Feeling of tightness in the chest and a } \\
\text { choking sensation) }\end{array}$ & 19 & 15 & 8 & 12 & 2.24 & 1.16 \\
\hline Recurrent nightmares & 21 & 12 & 9 & 12 & 2.22 & 1.19 \\
\hline $\begin{array}{l}\text { Feeling as though you are split into two } \\
\text { people and one of you is watching what } \\
\text { the other is doing }\end{array}$ & 22 & 15 & 7 & 10 & 2.09 & 1.14 \\
\hline Feeling powerless to help others & 25 & 11 & 7 & 11 & 2.07 & 1.20 \\
\hline Feeling unable to make daily plans & 25 & 12 & 7 & 10 & 2.04 & 1.16 \\
\hline Difficulty paying attention & 23 & 15 & 8 & 8 & 2.02 & 1.09 \\
\hline $\begin{array}{l}\text { Inability to remember parts of the most } \\
\text { hurtful events }\end{array}$ & 26 & 11 & 10 & 7 & 1.96 & 1.10 \\
\hline $\begin{array}{l}\text { Spending time thinking why God is } \\
\text { making you go through such events }\end{array}$ & 29 & 8 & 7 & 10 & 1.96 & 1.20 \\
\hline Feeling jumpy, easily startled & 26 & 10 & 13 & 5 & 1.94 & 1.05 \\
\hline $\begin{array}{l}\text { Having difficulty dealing with new situ- } \\
\text { ations }\end{array}$ & 26 & 14 & 6 & 8 & 1.93 & 1.10 \\
\hline $\begin{array}{l}\text { Blaming yourself for things that have } \\
\text { happened }\end{array}$ & 32 & 5 & 6 & 11 & 1.93 & 1.24 \\
\hline $\begin{array}{l}\text { Feeling that you are a jinx to yourself } \\
\text { and your family }\end{array}$ & 30 & 9 & 6 & 9 & 1.89 & 1.16 \\
\hline Unable to feel emotions & 28 & 14 & 5 & 7 & 1.83 & 1.06 \\
\hline $\begin{array}{l}\text { Troubled by bodily pain or physical } \\
\text { problems }\end{array}$ & 32 & 9 & 6 & 7 & 1.78 & 1.09 \\
\hline Feeling guilty for having survived & 34 & 5 & 8 & 7 & 1.78 & 1.13 \\
\hline Feeling others are hostile to you & 26 & 19 & 5 & 4 & 1.76 & 0.91 \\
\hline Poor memory & 32 & 10 & 6 & 6 & 1.74 & 1.05 \\
\hline $\begin{array}{l}\text { Feeling ashamed of the hurtful or trau- } \\
\text { matic events that have happened to you }\end{array}$ & 30 & 15 & 2 & 7 & 1.74 & 1.03 \\
\hline Feeling a need for revenge & 36 & 5 & 5 & 8 & 1.72 & 1.14 \\
\hline $\begin{array}{l}\text { Finding out or being told by other } \\
\text { people that you have done something } \\
\text { that you can't remember }\end{array}$ & 29 & 15 & 6 & 4 & 1.72 & 0.94 \\
\hline Hopelessness & 36 & 8 & 3 & 7 & 1.65 & 1.07 \\
\hline Feeling that you are the only one who & 38 & 4 & 6 & 6 & 1.63 & 1.07 \\
\hline
\end{tabular}


rience of traumatic events has a cumulative effect on mental health (Steet et al., 2009). The average number of traumatic experiences suffered by migrants was $17.74(S D=9.34$, range [1-36]). Effects were found based on the motives to migrate, $(F(1,52)=26.604$, $\left.p<.001, \eta^{2}=.338\right)$. Migrants motivated for economic reasons suffered an average of $12.15(S D=6.67)$ traumatic experiences, and refugees for political or religious reasons suffered an average of $22.93(S D=8.49)$.

\section{Torture experiences}

The most common type of torture (Table 4) was prolonged exposure to rain and/or cold (92.6\%), while $59.3 \%$ reported being exposed to strong heat, sun or light and $55.6 \%$ stated that they had been punched or slapped with objects in their attempt to cross the border. When referring to periods of detention of the border, $66.7 \%$ reported that they had been deprived of food and water for long periods of time, $66.7 \%$ reported that medical care had been withheld when required and $64.8 \%$ were exposed to dirty conditions leading to ill health. According to the migrants' testimonies, all the violence perpetrated by others was attributed to border agents. For instance, when they said that "were electrocuted" and "burned by cigarettes, electrically heated rods, hot oil, fire or corrosive acid," all of them (13\%) described having been wounded by electrical weapons such as tasers, except for two people who stated that they were burned by cigarettes. Similarly, the maintenance of actions that involved orders or deprivations such as "forced to stand for long periods of time," "photographed in sexual positions" or "subjected to mock executions," between others, took place under police custody or during the period of time between the arrest and the push-back.
The average number of torture experiences suffered was $9.02(S D=5.19$, range [0-27]). No effects were found based on the motives to migrate, $(F(1,52)=0.359, p=.552$, $\left.\eta^{2}=.007\right)$. Migrants motivated for economic reasons suffered an average of 8.58 ( $S D=$ 4.59 ) torture experiences, and refugees for political or religious reasons suffered an average of $9.43(S D=5.74)$.

\section{Psychological effects}

According to the HTQ, 27 out of 54 migrants/ refugees $(50 \%)$ met the criteria for PTSD diagnosis. The cumulative effect of traumatic experiences were positively associated with $\operatorname{PTSD}\left(F(1,52)=9.006, p<.01, \eta^{2}=.148\right)$. Migrants diagnosed with PTSD suffered an average of $21.30(S D=9.59)$ traumatic experiences, for $14.19(S D=7.73)$ traumatic experiences in no PTSD condition.

The number of torture experiences was not determinant to predict the aforementioned disorder. As such, for those who did not suffer from PTSD the number of torture events was $8.56(S D=5.20)$ compared to $9.48(S D=$ 5.22) who fulfilled the criteria for the diagnosis $\left(F(1,52)=0.425, p<.01, \eta^{2}=.148\right)$.

No significant differences were found due to motivation for migrate, $\left(\chi^{2}(1, \mathrm{~N}=54)=\right.$ $2.670, \mathrm{p}=.102)$. Ten migrants $(36.46 \%)$ for economic reasons and $17(60.71 \%)$ for persecution reasons were diagnosed PTSD.

The amount of trauma and torture experiences were related to the presence of psychological trauma symptoms; $(r(54)=.468$, $p<.001$, and $r(54)=.298, p<.05$ respectively). The greater negative experiences, the more presence of trauma symptoms. Table 5 shows frequencies and the average scores for each symptom.

\section{Discussion}

This study examines the prevalence of trau- 
matic events experienced by migrants/refugees throughout migratory transit and also in their home country, and how these experiences were associated with PTSD. Similarly, the study found the prevalence of other violent events perpetrated by police and border agents amongst the participants during JulyAugust 2019. The data showed differences in the number of traumatic events experienced by economic migrants and refugees for political and religious reasons. The latter suffered almost twice as many traumatic experiences as the former. However, in the present study no differences were found between refugees and economic migrants with regard to torture experiences and PTSD diagnosis. Since both have been in Bosnia for roughly the same time, they have suffered similar numbers of deportations, and economic migrants probably had no traumatic and torture experiences in their home country. These results could indicate that refugees for political/religious reasons experienced many more traumatic experiences because they add trauma suffered in their origin to those suffered during the trip and in their attempts to enter the EU. The reports of experiences of torture can then be assumed that occurred mostly during the trip and during pushbacks at the border.

To summarise, according to the data, during the trip and their stay in the EU border, migrants/refugees were subjected to a multitude of human rights violations including inhuman and degrading treatment. The data provides a better understanding of their situation (Crepet et al., 2017). Moreover, this data provides an insight into how politically supported systematic violence is directed toward refugees. However, as previous studies have pointed out, given the motivation to obtain protection there may be a tendency to overreport PTSD symptomatology (Peace \& Masliuk, 2011). This can po- tentially explain the difference in prevalence of PTSD as compared to other populations (Steel et al., 2009). The migrant population in both of these towns was almost exclusively made up of young, single males. This is unsurprising, given that gender differences also affect migratory processes. For example, vulnerable people, such as single women, unaccompanied minors or families may have been directed toward migration reception centres or safer areas (Crepet et al., 2017; Guarch-Rubio \& Manzanero, 2020). For instance, Bouhenia et al. (2017) found that in their work in Calais (France), local authorities frequently moved women and children to a separate offsite facility.

Similar to Arsenijević et al. (2017), our data indicates that while border closures in Balkan countries are associated with a considerable decline in arrivals, they may also be associated with an increase in violence and torture. As noted, European policies are based on political agreements that promote the externalization of borders whilst not openly condemning the use of violence as a deterrent. Border violence, therefore, includes the entire set of processes whereby migrants' somatic and mental capacities are repressed or destroyed both at and beyond the territorial border. The processes of border violence operate within the framework of contemporary "geopolitics of migration" (Hyndman, 2012) which is characterized by a global process of worsening the conditions for migration (selective, restrictive, repressive and punitive migration policies) through surveillance, detention and rendering migrants legally and economically precarious. Research e reveals the frequent violence and torture that migrants/refugees suffer by police and border agents in their attempt to reach the European Union (Arsenijevic et al., 2017; Crepet et al., 2017; Farhat et al., 2018; Koning, 2019). Psychologically, exposure to 
these violent episodes during transit serves to add to previous traumatic events and increases the risk of mental health issues for migrants and refugees (Dimitry, 2012; Manzanero et al., 2017).

However, despite the institutional violence and torture mentioned, just $40.7 \%$ perceived themselves as victims of torture, although this $51.9 \%$ of the interviewees felt humiliated and threatened by their experiences. The results of the current study support the argument that migrants constitute a vulnerable population experiencing often-ignored high rates of violence (Bouhenia et al., 2017). This should be brought to the attention of political and medical authorities as well as the general public.

The most frequent form of torture was exposure to rain or cold $(92.6 \%)$. This could be for two reasons. Firstly, it can partly be explained by the fact that many of the respondents, at the time of data collection, occupied empty factories that had been hastily converted into improvised accommodation centres that lacked basic amenities. This experience also exposed migrants to dirty conditions which was a risk for their health. Secondly, the reported exposure to rain and cold could be understood by the very nature of the migratory process. For example, travelling long distances on foot in extreme weather with little food or water. In addition, $59.3 \%$ had been exposed to strong heat, sun or light through the journey and $66.7 \%$ reported deprivation of food and water for long periods of time, during the border crossing or the push-backs. Similarly, in their work with Syrian-Kurdish refugees, Ibrahim and Hassan (2017) found that a high number of their respondents also reported being exposed to rain or cold. Therefore, the traumatic experiences described here can be explained by the conditions endured during the migratory process and also by institutional violence.

In addition, the capacity to respond to the influx of migrants in the region is strained, where centres at the time of data collection were close to capacity and limited sustainable alternatives existed (United Nations, 2018). Data suggests that in this region there is a systematic and organised element to the discrimination experienced by migrants. Relating to this, $66.7 \%$ of the respondents reported a lack of access to medical health care in Bosnia-Herzegovina. This is similar to the research conducted by Bouhenia et al. (2017) in Calais (France) who found aggravated health problems in migrants due to poor access to healthcare, often due to obstacles such as fear of detection, language barriers, transport issues and fear of racism. Adding to this, our findings echo Freedman (2016), who maintains that the current migration "crisis" in Europe is exposing the failure of the EU to offer real protection to those fleeing conflict and seeking refuge in Europe.

Limitations: One of the major limitations of this study is the small sample size. As such, this research is limited in its ability to make wider inferences. Qualitative research is also needed to understand the subjective perspective of the participants. Furthermore, under-reporting is a key concern for violence owing to the highly sensitive nature of the topic (Falb et al., 2013). On the other hand, another limitation may be an overestimation of data due to the use of an opportunistic sample likely with people who are more willing to talk about their traumatic experiences and who feel that their rights are more vulnerated. Finally, the last obstacle is that no medical nor psychiatric examination was conductED beyond applying the HTQ. Future research should assess reporting issues, as well as potential mechanisms and predictors of violence across settings, to identify potential 
protective characteristics to reduce the use of violence during attempted border crossings.

\section{Conclusion}

This research supports previous evidence of systemic and deliberate unofficial deportations, with frequent use of violence against migrants at the border between Bosnia-Herzegovina and Croatia (Amnesty International, 2019; Border Violence Monitoring Network, 2020). At a time that saw unprecedented numbers of people on the move toward Europe, studying the vulnerability of mobile populations, as well as the violence and trauma they suffer is of central importance.

This paper supports the claim that traumatic experiences have an effect on migrants/ refugees' mental health and can trigger the development of PTSD. This study has also shown how violence perpetrated by security forces against migrants is crystallized at the border-zones. Considering this, and notwithstanding the dearth of research in the context as described in the previous sections, there is a need for continued research that examines the conditions faced by migrants on the European borders. Furthermore, this article lends support to recent calls for an improved response from the EU to ensure the safety and human rights of migrants who are attempting to enter Europe along the Western Balkan route.

\section{Funding}

This work is part of a research project on assessment of memories and psychological disorders associated to trauma in refugees and victims of war, developed by the UCM Research Group on Eyewitness Testimony (ref. 971672), in the framework of the projects financed by Santander-Universidad Complutense de Madrid (PR26/16-20330, PR75/18-21661).

\section{Conflict of interest}

No potential conflict of interest was reported by the authors.

\section{References}

American Psychiatric Association. (1994). Diagnostic and statistical manual of mental disorders (4th ed.). Washington, DC: APA.

Amnesty International (2019). Pushed to the edge: Violence and abuse against refugees and migrants along the Balkans Route. https://www.amnesty.org/ en/documents/eur05/9964/2019/en/

Arsenijević, J., Schillberg, E., Ponthieu, A., Malvisi, L., Ahmed, W. A. E., Argenziano, S., Zamatto, F. ... de Vingne, B. (2017). A crisis of protection and safe passage: violence experienced by migrants/refugees travelling along the Western Balkan corridor to Northern Europe. Conflict and Health, 11, 1-9. https://doi.org/10.1186/s13031017-0107-z

Border Violence Monitoring Network (2020). Illegal push-backs and border violence reports. Balkan Region. December 2019. https://www. borderviolence.eu/wp-content/uploads/ December-Report-2019.pdf

Başoğlu, M., Livanou, M., Crnobarić, C., Frančišković, T., Suljić, E., Đurić, D., \& Vranešić, M. (2005). Psychiatric and cognitive effects of war in former Yugoslavia: Association of lack of redress for trauma and posttraumatic stress reactions. Fama, 294(5), 580-590. https://doi. org/10.1001/jama.294.5.580

Beşer, M. E., \& Elfeitori, F. (2018). Libya Detention Centres: A State of Impunity. Ankara: Migration Policy Center. https://aybu.edu.tr/gpm/contents/ files/enesbeser.pdf

Bouhenia, M., Farhat, J.B., Coldiron, M.E., Abdallah, S., Visentin, D., Neuman, M., Berthelot, M., Porten, K., \& Cohuet, S. (2017). Quantitative survey on health and violence endured by refugees during their journey and in Calais, France. International Health, 9, 335-342. https:// doi.org/10.1093/inthealth/ihx040

Crepet, A., Rita, F., Reid, A., Van den Boogaard, W., Deiana, P., Quaranta, G., Barbieri, A., \& Di Carlo, S. (2017). Mental health and trauma in asylum seekers landing in Sicily in 2015: a descriptive study of neglected invisible wounds. Conflict and Health, 11, 1-11. https://doi. org/10.1186/s13031-017-0103-3

Dimitry, L. (2012). A systematic review on the mental health of children and adolescents in areas of armed conflict in the Middle 
East. Child: Care, Health and Development, 38, 153-161. https://doi.org/10.1111/j.13652214.2011.01246.x

El-Shaarawi, N., \& Razsa, M. (2019). Movements upon movements: Refugee and activist struggles to open the Balkan route to Europe. History and Anthropology, 30, 91-112. https://doi.org/10.1080/ 02757206.2018.1530668

Falb, K. L., McCormick, M. C., Hemenway, D., Anfinson, K., \& Silverman, J. G. (2013). Violence against refugee women along the Thai-Burma border. International fournal of Gynecology $\mathbb{E}$ Obstetrics, 120, 279-283. https://doi.org/10.1016/j. ijgo.2012.10.015

Farhat, J. B., Blanchet, K., Juul Bjertrup, P., Veizis, A., Perrin, C., Coulborn, R. M., Mayaud P., \& Cohuet, S. (2018). Syrian refugees in Greece: experience with violence, mental health status, and access to information during the journey and while in Greece. BMC Medicine, 16, 1-12. https:// doi.org/10.1186/s12916-018-1028-4

Freedman, J. (2016). Engendering security at the borders of Europe: women migrants and the Mediterranean 'crisis'. Fournal of Refugee Studies, 29, 568-582. https://doi.org/10.1093/jrs/few019

Guarch-Rubio, M. \& Manzanero, A.L. (2020). Credibility and testimony in asylum procedures with unaccompanied refugee minors. European Fournal of Migration and Law, 22(2), 257-271. https://doi.org/10.1163/15718166-12340076

Holmes, S. M., \& Castañeda, H. (2016). Representing the "European refugee crisis" in Germany and beyond: Deservingness and difference, life and death. American Ethnologist, 43, 12-24. https://doi.org/10.1111/ amet. 12259

Hyndman, J. (2012). The geopolitics of migration and mobility. Geopolitics, 17, 243-255. https://doi.org/ 10.1080/14650045.2011.569321

Ibrahim, H., \& Hassan, C. Q. (2017). Posttraumatic stress disorder symptoms resulting from torture and other traumatic events among Syrian Kurdish refugees in Kurdistan Region, Iraq. Frontiers in Psychology, 8, 241-249. https:// doi.org/10.3389/fpsyg.2017.00241

Infante, C., Idrovo, A. J., Sánchez-Domínguez, M. S., Vinhas, S., \& González-Vázquez, T. (2012). Violence committed against migrants in transit: experiences on the Northern Mexican border. Fournal of Immigrant and Minority Health, 14, 449-459. https://doi.org/10.1007/ s10903-011-9489-y

International Organization for Migration (IOM). (2020). Flow monitoring surveys: Bosnia and Herzegovina 2019. https://bih.iom.int/sites/default/
files/BiH2019report.pdf

International Organization for Migration (IOM) (2020). Key Migration Terms._https://www.iom.int/ key-migration-terms

Karamanidou, L. (2016). Violence against migrants in Greece: beyond the Golden Dawn. Ethnic and Racial Studies, 39, 2002-2021. https://doi.org/10. 1080/01419870.2015.1124124

Koning, S. M. (2019). Displacement contexts and violent landscapes: How conflict and displacement structure women's lives and ongoing threats at the Thai-Myanmar border. Social Science \& Medicine, 240, 1-9. https://doi. org/10.1016/j.socscimed.2019.112557

Manzanero, A. L., Crespo, M., Barón, S., Scott, M. T., El-Astal, S., \& Hemaid, F. (2017). Traumatic events exposure and psychological trauma in children victims of war in the Gaza Strip. Fournal of Interpersonal Violence. First published November 23, 2017. https://doi. org/10.1177/0886260517742911

Meçe, M. H. (2018). Risk Factors of the Irregular Migratory Waves on the Western Balkan Route: Implications in the European Union Countries. In E. Balica \& V. Marinescu (Eds), Migration and Crime. Realities and Media Representations (pp. 4567). Cham, Switzerland: Palgrave Macmillan

Milan, C. (2019). Refugees at the gates of the EU: Civic initiatives and grassroots responses to the refugee crisis along the western Balkans route. Fournal of Balkan and Near Eastern Studies, 21, 43-60. https://doi.org/10.1080/19448 953.2018.1532686

Peace, K. A., \& Masliuk, K. A. (2011). Do motivations for malingering matter? Symptoms of malingered PTSD as a function of motivation and trauma type. Psychological Injury and Law, 4(1), 44-55. https://doi.org/10.1007/s12207-0119102-7

Pérez-Sales, P. (2018). Migration and torture: Building a map of knowledge. Torture fournal, 28(2), 1-14. https://doi.org/10.7146/torture. v28i2.106906

Reques, L., Rolland, C., Aranda, E., Grippon, A., Fallet, N., Bensimon, C., ... \& Luhmann, N. (2019). Episodes of violence suffered by migrants transiting Libya, Italy and France. European Fournal of Public Health, 29(Supplement 4). https://doi.org/10.1093/eurpub/ckz186.046

Shoeb, M., Weinstein, H., \& Mollica, R. (2007). The Harvard trauma questionnaire: adapting a cross-cultural instrument for measuring torture, trauma and posttraumatic stress disorder in Iraqi refugees. International fournal of Social Psychiatry, 53, 447-463. https://doi. 
org/10.1177/0020764007078362

Silva, E. A., Manzanero, A. L., Bengoa, G., \&

Contreras, M. J. (2018). Indicadores de trata de personas en mujeres que ejercen la prostitución en locales de alterne de la Comunidad de Madrid (España) [Indicators of trafficking in Women Practicing Prostitution in strip clubs in the Community of Madrid (Spain)]. Acción Psicológica, 15(1), 1-16. https://doi.org/10.5944/ ap.15.1.19864.

Steel, Z., Chey, T., Silove, D., Marnane, C., Bryant, R. A., \& Van Ommeren, M. (2009). Association of torture and other potentially traumatic events with mental health outcomes among populations exposed to mass conflict and displacement: a systematic review and meta-analysis. Fama, 302(5), 537-549. https://doi.org/10.1001/ jama.2009.1132

United Nations High Commissioner for Refugees (UNHCR) (2018). Refugee and Migrant Situation in Bosnia and Herzegovina. https://data2.unhcr. org/es/documents/download/63869

United Nations High Commissioner for Refugees (UNHCR) (2019). Global Trends: Forced Displacement in 2018. https://www.unhcr. org/5d08d7ee7.pdf

United Nations High Commissioner for Refugees (UNHCR) (2020). Global Trends: Forced Displacement in 2019. https://www.unhcr. org/5ee200e37.pdf

United Nations High Commissioner for Refugees (UNHCR) (2020). Bosnia and Herzegovina: United Nations Country Team Operational Update, Refugee and Migrant situation-December 2019. https://data2.unhcr.org/en/documents/ download/74293

Veronese, G., Pepe, A., \& Vigliaroni, M. (2019). An exploratory multi-site mixed-method study with migrants at Niger transit centers: The push factors underpinning outward and return migration. International Social Work. https://doi. org/10.1177/0020872818819736 